\title{
Delayed Circadian Rhythms and Pars Tuberalis Dysfunction in Mood Disorders
}

\author{
Daniel F. Kripke \\ Department of Psychiatry, University of California, San Diego, CA, USA
}

Professor Lee's discussion of circadian misalignment associated with bipolar disorder explained the convincing evidence that circadian rhythm phase delaying is associated with bipolar disorder [1]. Indeed, much objective evidence indicates behavioral association, as well as evidence of causality, both for bipolar disorder and for unipolar major depressions. The skin fibroblasts from bipolar patients grown in tissue culture in-vitro had longer free-running circadian periods [2]. Moreover, the subjective chronotype (e.g., degree of delayed sleep phase) of bipolar patients predicted their response to lithium, with the more delayed patients having poorer responses [3]. This corresponds to other evidence from cell cultures that depressed patients have longer intrinsic circadian rhythms in vitro [4]. Associations with particular genetic polymorphisms have been suggested. In a broader sense, massive genome-wide association studies and Mendelian randomization analyses confirmed the causal role of genetic polymorphisms in circadian rhythm characteristics and resultant mood variations [5].

The responses of bipolar patients to morning bright light therapy, wake therapy, and imposed sleep schedule advances confirm the relevance of circadian interventions to therapeutic management $[6,7]$.

It has been suggested that morning bright light, by suppressing morning melatonin, facilitates hypothalamic pars tuberalis release of thyrotropin (T3) into the hypothalamus, with subsequent regulation of pituitary gonadotropins and ACTH [8]. Lack of adequate light or too much light at unfavorable times may lead to pars tuberalis dysfunction.

Received: January 14, 2020 Accepted: January 28, 2020

Corresponding author: Daniel F. Kripke, MD, 7450 Olivetas Ave \# 380, La Jolla, CA 92037, USA.

Tel: 1-858-453-6427, E-mail: dankripke@gmail.com

(c) This is an Open Access article distributed under the terms of the Creative Commons Attribution Non-Commercial License (https://creativecommons.org/ licenses/by-nc/4.0) which permits unrestricted non-commercial use, distribution, and reproduction in any medium, provided the original work is properly cited.
Professor Lee's group has introduced a novel model of the relationships of circadian phase advances and delays to depression and mania among bipolar patients. In his Figure 3, he proposed a satisfying explanation for the surprising peaks of major depressions and suicides in the spring and early summer months, with peaks of mania observable at almost the same time or only a bit later in the year than depression [1]. Although dawn appearing earlier in the spring might seem antidepressant for many winterdepressed patients, by increasing morning therapeutic bright light, those most severely phase-delayed might experience increasingly early dawn as exacerbating phase delays, making depression more severe by exacerbating pars tuberalis dysfunction.

The more morning daylight delays a patient's phase-response curve, the more some depressed patients might experience increasingly extreme phase delays: thus increased depression. As Professor Lee suggested, extreme phase delays may conversely function as phase advances such as those he has found associated with a switch to mania. Thus, the bright mornings of spring and early summer might account for the observed peaks of depression and mania in spring and summer. The sudden spring introduction of the daylight-savings time-reference may contribute to triggering spring-summer exacerbations.

The remarkable observations of Professor Lee's group should be replicated and extended by other clinicians. The valuable ideas suggest key considerations in optimizing the treatment of bipolar disorders. Perhaps young Korean investigators are becoming the leaders in this field. Much more clinical investigation is needed to detail the circadian phase abnormalities associated with bipolar exacerbations, to increase our understanding of the malsynchronization developing between various circadian functions, and to explore the role of pars tuberalis dysfunction in bipolar and unipolar mood disorders.

\section{Acknowledgments}

None 


\section{Conflicts of Interest}

The author has no potential conflicts of interest to disclose.

\section{ORCID iD}

Daniel F. Kripke (D)

https://orcid.org/0000-0002-2318-8179

\section{REFERENCES}

1. Lee HJ. Circadian misalignment and bipolar disorder. Chronobiol Med 2019;1:132-136.

2. McCarthy MJ, Wei H, Marnoy Z, Darvish RM, McPhie DL, Cohen BM, et al. Genetic and clinical factors predict lithium's effects on PER2 gene expression rhythms in cells from bipolar disorder patients. Transl Psychiatry 2013;3:e318.

3. McCarthy MJ, Wei H, Nievergelt CM, Stautland A, Maihofer AX, Welsh
DK, et al. Chronotype and cellular circadian rhythms predict the clinical response to lithium maintenance treatment in patients with bipolar disorder. Neuropsychopharmacology 2019;44:620-628.

4. Shi SQ, White MJ, Borsetti HM, Pendergast JS, Hida A, Ciarleglio CM, et al. Molecular analyses of circadian gene variants reveal sex-dependent links between depression and clocks. Transl Psychiatry 2016;6:e748.

5. Jones SE, Lane JM, Wood AR, van Hees VT, Tyrrell J, Beaumont RN, et al. Genome-wide association analyses of chronotype in 697,828 individuals provides insights into circadian rhythms. Nat Commun 2019;10:343.

6. Tseng PT, Chen YW, Tu KY, Chung W, Wang HY, Wu CK, et al. Light therapy in the treatment of patients with bipolar depression: a meta-analytic study. Eur Neuropsychopharmacol 2016;26:1037-1047.

7. Humpston C, Benedetti F, Serfaty M, Markham S, Hodsoll J, Young AH, et al. Chronotherapy for the rapid treatment of depression: a meta-analysis. J Affect Disord 2020;261:91-102.

8. Kripke DF, Elliott JA, Welsh DK, Youngstedt SD. Photoperiodic and circadian bifurcation theories of depression and mania. F1000Res 2015;4:107. 